\title{
SUSTAINABLE DEVELOPMENT REQUIRES ENVIRONMENTAL JUSTICE
}

\author{
MICHAEL J. ELLERBROCK \\ Professor \& Undergraduate Director, Agricultural \& Applied Economics, Virginia Tech, USA.
}

\begin{abstract}
As an appointed member of the U.S. Environmental Protection Agency's National Environmental Justice Advisory Council (NEJAC), Ellerbrock meets with local stakeholders and participates in public hearings across the nation in which poor and minority communities suffer disproportionally from chemical exposure, pollution incidents and aesthetic degradation. In this paper, we begin by looking at what three core disciplines - economics, ecology and ecumenism - have in common. Often perceived today as philosophic enemies, the disciplines have common roots in the ancient Greek notion of a household - oikos. Integrating the roots of economics, ecology and ecumenism reveals a tri-partite household that must be managed in harmony for it to be sustainable. In light of violent conflicts (historical and current) over economic resources, political worldviews and religious values, ecumenism is a critical factor aimed at mutual understanding, respect and collaboration among diverse groups. Locally and globally, true peace is more than the absence of conflict/war. A key component of quality of life, Environmental Justice (EJ) is a necessary, though not sufficient, condition for sustainable development.

Keywords: consensus-based solutions, economic ethics, ecumenism, environmental justice, environmental racism, oikos household, success stories, sustainable development, U.S. EPA.
\end{abstract}

\section{INTRODUCTION}

In this paper, let's explore what three core disciplines - economics, ecology and ecumenism - have in common regarding sustainable development. Often perceived today as philosophic enemies, the disciplines share roots in the ancient Greek notion of a household - oikos [1,2]. In their etymological meanings, the disciplines were originally defined as:

- Economics - study of the management of the household's financial resources;

- Ecology - study of the management of the household's physical resources;

- Ecumenism - study of the management of the household's moral, ethical and spiritual resources amidst a plurality of values. A good listener, an ecumenical person is a synthesizer who seeks consensus among various perspectives and traditions.

The household is defined, not by the area of central overlap but rather, by the entire biosphere within which economics, ecology, and ecumenism - indeed all disciplines - operate (Fig. 1). There is only one household, though we as individuals are personally responsible for only parts of it. However, since all dimensions of the household are connected via the Natural, Social and Philosophic Sciences, we can legitimately place ethical demands upon those individuals and institutions responsible for the rest of the household.

The choice of definitions we use can set the stage for conflict. Some scholars argue that the disciplines are hopelessly split because they serve or have adopted competing goals: economics - human welfare maximization, ecology - species' survival, ecumenism - moral freedom [2]. Other scholars are more optimistic [3, 4]. If we are to integrate the best insights each discipline has to offer about life on earth, then recovery of the notion of a household may serve as a common metaphor for fruitful conversation [5]. 


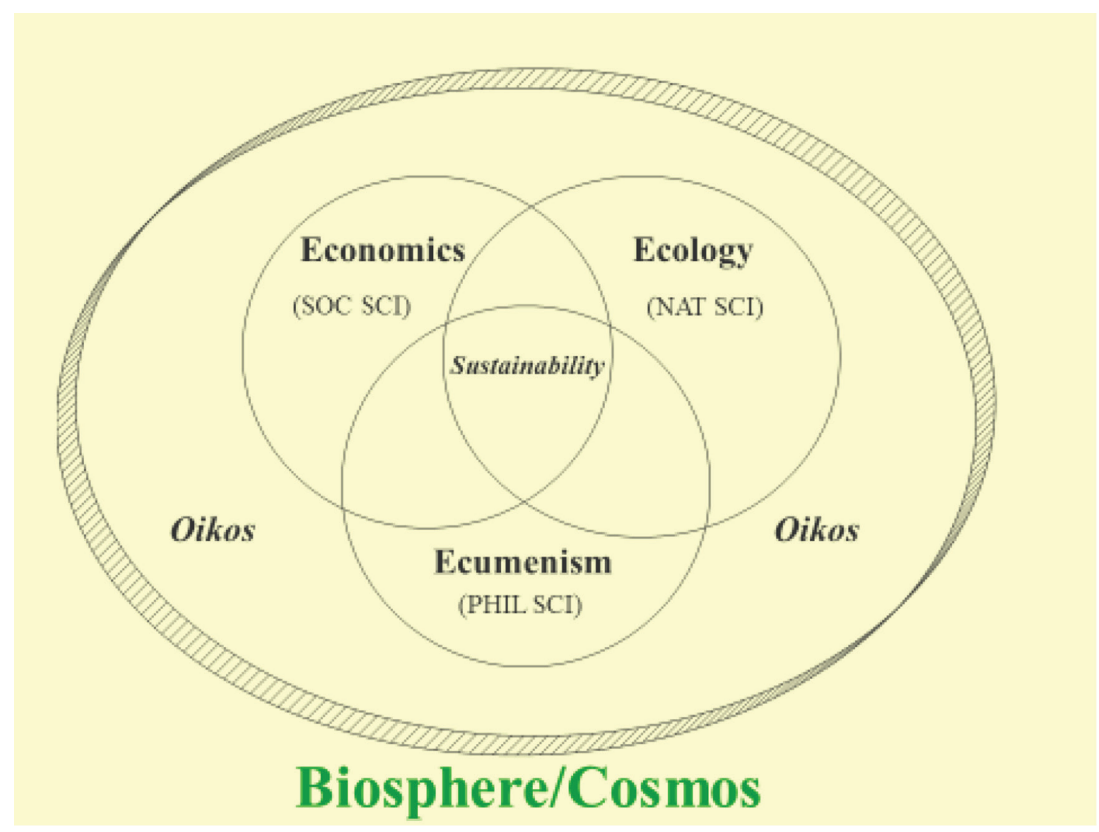

Figure 1: A Holistic View of the Household.

Like a three-legged stool, the household is sustainable only if all three dimensions are managed in harmony. We have to cost-effectively pay the bills. We have to be wise stewards of the physical resources. We have to get along with each other, amidst a plurality of values.

This holistic paradigm emphasizes recognition of the complex interrelationships at play throughout the household, cooperation in meeting the needs of different members of the household, and tolerance of diverse views within the household. The Philosophic Sciences study human values via art, ecumenism, literature, music, philosophy, poetry, psychology, theater, theology, et al. In light of violent conflicts (historical and current) over economic resources, political worldviews and religious values, ecumenism is a critical factor aimed at mutual understanding, respect and collaboration among diverse groups. Locally and globally, true peace is more than the absence of conflict/war.

Undermining ecumenism, our relationships are not stable if people feel marginalized, under-valued, exploited for others' gain, forced to live or work in dangerous or polluted places. A key component of quality of life, Environmental Justice (EJ) is a necessary, though not sufficient, condition for sustainable development.

\section{DIMENSIONS OF ENVIRONMENTAL JUSTICE}

Environmental Justice (EJ) involves several key factors: control over one's local destiny and quality of life; capacity to be engaged in the distribution of resources; equitable flow of power and political mobilization; institutional context and cultures; environmental decision-making processes and outcomes; and meaningful involvement. In terms of environmental benefits and costs, EJ includes consideration of the relative distribution of those outcomes.

- Racism - data show race to be an 'independent predictor' distinct from social class, cultural values, or other factors regarding lead poisoning in children [6], exposure to air 
pollution [7-10], contaminated fish consumption [11], location near municipal landfills and incinerators [12, 13] and abandoned toxic waste dumps [14]. In other words, at all levels of income (not only poor), black and brown citizens in many regions are disproportionately exposed to environmental hazards, toxic substances and aesthetic degradation relative to white citizens. Hence, the legitimate attainment of wealth cannot fully explain white Americans' higher quality of life.

- EJ Movement - parallels other U.S. historical movements: Women's, Native Americans,' Labor, Civil Rights, Environmental; the movement has been catalyzed by academic research.

- Decreasing Health Care Access - double whammy effect on the poor: higher incidence of exposure and lesser affordability of medical insurance and services.

- Citizens' Ability to 'Vote with their Feet' - personal mobility is primarily a function of economic wealth, educational level, social networks, and professional status; thus it is a copout to blame the poor victims who lack the capacity to easily move to a better town and start life over for their family.

- Segregation in the U.S. - a post-1900 phenomenon, prior to Civil War in 1860's, most U.S. cities were integrated; thus it is a copout to say that urban segregation is natural and has always been with us [15].

- Subsidiarity - a principle of social ethics that those who have to live with the consequences of a decision should get to make the decision, or at least be meaningfully involved in the decision-making process; to have primary control over one's lifestyle; counters white privilege; a principle advocated by many religions and social ethicists.

- Democracy - though the fairest form of government, it is not perfect. In terms of influencing neighborhood quality, minorities often experience democracy as 'three wolves and a lamb voting on lunch.' Majority rule speaks for itself when elected officials decide the location of the next incinerator, landfill, refinery or prison.

- Literacy - when marginalized communities attempt to participate in environmental planning processes, less educated citizens can be hindered by a lack of language proficiency and/or intimidated by legal/scientific jargon. Allowing such factors as limited education to govern the outcome heightens the ethical injustice in the structural system.

- Free Market Forces - should we rely on individuals' entrepreneurial skills to determine/influence residential and occupational choices or collectively adopt an Economic Baseline or Threshold of factors (economic, environmental, social) below which no one should have to live? How do we balance personal freedom with absolute human rights to a minimum quality of life? Does 'a rising tide lift all boats' or is it a Zero-Sum game?

- Individual vs Institutional Discrimination - U.S. Supreme Court ruling (1976) that requires evidence of intent and identification of specific agents/perpetrators, must be overt and deliberate with a "single bad actor" [15].

- Rawls' Social Contract Theory - a society's moral behavior can be judged by the way its worst off are treated, asserted in his noted treatise A Theory of Justice: 'Each person possesses an inviolability founded on justice that even the welfare of society as a whole cannot override' [16].

- Pervasive Cycle of Quiescence - giving in, giving up, feeling defeated, opting out; pessimistically adopting a sense of hopelessness and anomie: no one cares about me ... so why should I care? 


\section{AMERICA'S EJ MOVEMENT}

For years, beginning with the United Church of Christ's landmark 1987 study Toxic Wastes and Race in the United States, human rights activists and environmental scholars tried to call public attention to the problem of environmental injustice and its most virulent expression in environmental racism [17]. Yet, for many reasons - political apathy, economic rationalization, moral indifference, sheer busyness - their call fell on many deaf ears. America's EJ movement was stuck in slow motion.

When The Big Easy (New Orleans) became The Big Flush in August of 2005, Hurricane Katrina's lessons sparked a national awakening to the reality that millions of poor and racial minorities were disproportionately exposed to environmental hazards. Katrina's aftermath lifted the carpet under which large numbers of citizens lay hidden. Yet, Katrina was not unforeseen.

Similarly, the British Petroleum Deepwater Horizon oil spill in April 2010 devastated lives, property, barrier islands, tourism and fishery economies along the entire Gulf Coast, inflicting the most pain on less resilient minority counties that permanently lost significant population. In a phenomenon termed the Goods Movement, many minority neighborhoods around the U.S. suffer alarming rates of public health issues due to breathing diesel fumes from 20-40,000 trucks per day traveling through their neighborhoods. Many retail 'Dollar Stores' serve poor communities, yet sell plastic products and toys that children might chew on, which contain potentially dangerous chemicals, e.g. phthalates.

Ethical considerations are vital in assessing the virtues of economic structures and systems. When benefits and costs are not distributed equitably, an ethical challenge exists. Policies that accrue benefits to a focused few while dispersing the costs across many (often unaware) citizens are politically easy to pass, e.g. tariffs on imports that protect a few domestic jobs (and gain passionate votes), yet impose costs across many dispersed consumers through higher prices and reduced choices.

Conversely, environmental injustice/racism raises ethical challenges in the reverse by exploiting the lives of a powerless few by exposing them to environmental hazards in order to produce goods and services for many dispersed well-off citizens, e.g. migrant farm workers and coal miners generating food and electricity for the masses. Who would vote against those systems?

When approached from a human rights perspective, the U.S. EJ movement has recently captured some public attention and catalyzed some policy efforts at the national, state and local levels to prevent and remediate cases and situations of environmental injustice in the workplace, neighborhood, highway, and waterway. However, much work remains, including building or rebuilding trust among citizens, industry, government, academia, religions and activist organizations.

\section{CONSENSUS-BASED SOLUTIONS}

Complex social/environmental problems necessitate consensus-building processes that are inclusive, comprehensive and transparent. Grassroots efforts to facilitate groups of diverse stakeholders in proactively developing organic, deliberative and sustainable solutions are labor-intensive undertakings, yet usually worth the investment of participants' time and resources. A beginning point for achieving win-win solutions is nurturing everyone to approach the collective table with two key attitudes: tetsugen and higher ground.

A Zen concept, tetsugen means to 'be as aware of the world around you and others as the fish that is aware of the water!' Having genuine empathy for others' lives opens the doors to mutual understanding, interpersonal trust, and reconciliation of diverse interests. Without trust, civic processes can remain painfully adversarial. 
The concept of higher ground builds on the notion of common ground. Whereas common ground seeks solutions that meet everyone's independent needs, higher ground goes a step further when each participant defines their needs as including the needs of all other stakeholders. In other words, 'My needs are not met unless your needs are also met!'

Conducting effective stakeholder meetings is an art and science. Several initial steps should not be taken lightly, glossed over by assuming that everyone already agrees on the process, meaning of terms and the agenda. Critical factors include: identifying and recruiting all stakeholders, holding meetings at times and places convenient to all participants, whether to have media present, establishing ground rules, deciding how to decide, defining 'consensus.'

Skeptics may begin by asking two important questions: 'Who is missing, not at the table? Who framed the debate, defined the problem, what is the real issue(s)?' Eliciting whole group buy-in warrants substantive and transparent answers and dialogue to everyone's satisfaction.

In facilitating the content and tone of group discussions, objectivity and subjectivity are complementary factors. Heads and hearts are both relevant. Scientific facts and financial limitations are fundamental pieces of information. Expressing emotional passion is relevant, important and fruitful, as long as it includes empathy for others' feelings, experiences and perspectives. Respecting and reconciling differences in human values can be the most challenging task.

\section{RECENT U.S. FEDERAL ACTIONS}

In 1990, a Workgroup within the U.S. Environmental Protection Agency (EPA) investigated alleged cases of environmental injustice and possible racism, which led to establishment of:

- $\quad$ EPA Office of EJ to integrate EJ into federal policies and procedures (1992);

- National Environmental Justice Advisory Council (NEJAC) to advise EPA Administrator regarding specific situations and possible solutions (1993);

- President Clinton issues Executive Order 12898 mandating inclusion of EJ into the mission of all federal agencies (1994);

- Interagency Task Force includes 17 federal agencies adopting EJ in their missions (2016).

In the last eight years, the EPA has taken the initiative on several EJ fronts:

- Establishment of a Federal Interagency Work Group with 17 members;

- Development of an online EJ screening tool to enable localities and communities to evaluate empirically whether they are experiencing environmental injustice;

- Increased funding by $\$ 50$ million annually for protection of tribal lands;

- Additional funds for industry fence line monitoring grants;

- Consent decree authorizing no-cost share grants for upgrading emissions equipment in school bus fleets;

- Pesticide safety education grants in multiple languages to protect mothers and children;

- Research and scientific studies of point source pollution in major ports and highway corridors in minority communities;

- Development of EJ2020 - a long-range strategic plan to promote EJ.

\section{SELECTED LOCAL SUCCESS STORIES}

U.S. EPA works closely with the 50 states' Department of Environmental Quality (DEQ), Department of Natural Resources (DNR), et al. The relationship frequently turns adversarial 
regarding laws and issues of compliance. Fortunately, many examples exist of positive cooperation, including:

- Air Quality - AK Steel agreed to reduce particulate matter emissions from its steel and iron plant (Michigan);

- Soil Restoration - EPA and Oconto County Solid Waste (Wisconsin) removed and recycled thousands of cubic yards of soil contaminated by electronic waste;

- Emergency Response - Federal, state and local stakeholders worked quickly and effectively to clean up and track dangerous chemicals that exploded in a major fire at Rowayton Trading's plant (Connecticut);

- Brownfield Revitalization - diverse stakeholders leveraged Brownfields grants to invest in the Manchester Lawrence Rail Road (Massachusetts) and conduct job training in site remediation and water management;

- Waste Recycling - diverse stakeholders in Conejos and Costillos Counties (Colorado) used an EPA grant to address illegal waste dumping in the San Luis Valley and established waste collection and transfer facilities;

- Sustainable Living - in their Making a Visible Difference (MVD) project, EPA and Poplar (Montana) officials worked with the Assiniboine and Sioux Tribes to build LEED Platinum homes through the Make-It-Right Foundation;

- Smart Growth - EPA and worked with diverse local groups through the Queen City Crossing \& 6th Ward Neighborhood MVD Project (Montana) to remediate brownfields, refurbish vacant properties, improve pedestrian access, redirect car and bicycle flow, invest in equitable mixed-use development, and install urban green space.

These examples reflect many collaborative efforts across the U.S. that have integrated EJ concerns into regional and local strategic plans for sustainable development. When all levels of government, industry and citizenry seek higher ground, intertemporal social welfare is usually maximized [18].

\section{CONCLUSION}

A necessary, though not sufficient, condition for sustainable development, EJ is ultimately about power: who has it, how is it used, how is it gained and what are its fruits?

Are all stakeholders fairly represented? Having learned the hard way, elder minorities bluntly warn their children: 'If you're not at the table, you're on the menu!'

Maintaining our household requires wisdom. Who will speak for the voiceless: the uninformed neighbor, naïve consumers, silent majority, future citizens, wildlife and nature itself? True statesmanship sees beyond one's own backyard.

Sustainable development demands a collective vision based on interpersonal trust, reciprocal sacrifice, shared power and intergenerational commitments. Building civic trust requires empathy. Empathy is hard work, yet its fruits are tangible and enduring, for we journey together on spaceship Oikos. EJ offers a sustainable path.

\section{REFERENCES}

[1] Meeks, M.D., God and land. Agriculture and Human Values, 2(4), pp. 16-27, 1985. https://doi.org/10.1007/BF01530674

[2] Young, M.D., Sustainable Investment and Resource Use: Equity, Environmental Integrity, and Economic Efficiency, Park Ridge: Parthenon Publishing, 1992. 
[3] Costanza, R. (ed.), Ecological Economics: The Science and Management of Sustainability, New York, NY: Columbia University Press, 1991.

[4] Daly, H.E. \& Cobb, J.B Jr., For the Common Good: Redirecting the Economy Toward Community, the Environment, and a Sustainable Future, Boston, MA: Beacon Press, 1994.

[5] Haught, J.F., The Promise of Nature, New York, NY: Paulist Press, 1993.

[6] Agency for Toxic Substances \& Disease Registry. The Nature and Extent of Lead Poisoning in Children in the United States: A Reprint to Congress, Atlanta: U.S. Department of Health \& Human Services, 1988.

[7] Freeman, M.A., The distribution of environmental quality. Environmental Quality Analysis, ed. A.V. Kneese \& B.T. Bower, Baltimore: Johns Hopkins Press, 1971.

[8] Gelobter, M., The distribution of air pollution by income and race," Paper presented at the 2nd Symposium on Social Science, Urbana, IL, June 1988.

[9] Gianessi, L., Peskin, H.M. \& Wolff, E., The distributional effects of uniform air pollution policy in the U.S. Quarterly Journal of Economics, 93(2), 281-301, 1979. https://doi.org/10.2307/1883195

[10] Wernette, D.R. \& Nieves, L.A., Breathing polluted air. EPA Journal, 18, pp. 16-17, 1992.

[11] West, P.C., Fly, F. \& Marans, R., Minority anglers and toxic fish consumption: evidence from a state-wide survey of michigan. Proceedings of the Michigan Conference on Race and the Incidence of Environmental Hazards, ed. B. Bryant \& P. Mohai, Ann Arbor: University of Michigan School of Natural Resources, 1989, pp. 108-122.

[12] Bullard, R.D., Dumping in Dixie: Race, Class and Environmental Quality, Boulder, CO: Westview Press, 1990.

[13] Bullard, R.D. \& Wright, B.H., Environmentalism and the politics of equity: Emergent trends in the black community. Mid-American Review of Sociology, 12, pp. 21-37, 1986.

[14] United Church of Christ Commission for Racial Justice, Toxic Wastes and Race in the United States: A National Report on the Racial and Socio-Economic Characteristics of Communities with Hazardous Waste Sites, New York, NY: United Church of Christ, 1987.

[15] Cole, L.W. \& Foster, S.R., From the Ground Up: Environmental Racism and the Rise of the Environmental Justice Movement, New York, NY: New York University Press, pp. 63-66, 2001.

[16] Rawls, J., A Theory of Justice, Boston: Harvard University Press, p. 560, 1971.

[17] United Church of Christ, Toxic Wastes and Race: A National Report on the Racial and Socio-Economic Characteristics of Communities with Hazardous Waste Sites, New York, NY: UNCC, 1987.

[18] Dukes, F., Stephens, J.B. \& Piscolish, MA., Reaching for Higher Ground: Creating Purpose-driven, Principled, and Powerful Groups, Charlottesville: Dukes, Piscolish \& Stephens, 2008. 